\title{
Views of Teachers, Parents, and Counselors toward the Preschool Version of First Step to Success Early Intervention Program (FSS-PSV) in Preventing Antisocial Behaviors
}

Aysun Çolak ${ }^{a}$

Anadolu University

Arzu Arıkan ${ }^{d}$

Anadolu University

\author{
Gözde Tomris ${ }^{b}$ \\ Anadolu University \\ Funda Aksoy ${ }^{\mathrm{e}}$ \\ Anadolu University
}

Ibrahim H. Diken ${ }^{c}$

Anadolu University

Seçil Çelik

Anadolu University

Abstract

This study aims to describe the views of teachers, parents, and FSS-PSV counselors on the Preschool Version of First Step to Success Early Intervention Program (FSS-PSV) in preventing antisocial behaviors; in addition, the implementation process and contributions from the program will also be outlined. The study was conducted in six different preschools in Eskisehir, Turkey. Participants of the study were 11 preschool teachers, 11 parents, and six FSS-PSV counselors. Data were collected through semi-structured interviews. Descriptive analysis was used in analyzing the data. As a result, children who were identified as target students of the FSS-PSV program revealed having antisocial/problem behaviors. These behaviors particularly involved physical aggression and incompetency in social skills. The majority of teachers and parents stated that those behaviors stemmed from family-related reasons. To cope with antisocial/problem behaviors, the teachers preferred to talk to a student about his/her behavior, use the in- and out-of-class break technique, and reward positive behaviors. Parents preferred talking to the child or punishing them. Qualitative findings of this study support the findings of studies on the effectiveness of FSS-PSV through quantitative methods in literature. Similarly, most of the participants in this study provided positive feedback on FSS-PSV, and changes were observed concerning the antisocial/problem behaviors of the children.

Keywords: Preschool period $\bullet$ Antisocial behaviors $\bullet$ Prevention of antisocial behaviors $\bullet$ First Step to Success Early Intervention Program $\bullet$ Qualitative research

* This research is a summary of Master Thesis of the second author (Gözde Tomris) and was supported in part by grants directed by Prof. Ibrahim H. Diken and supported from The Scientific and Technological Research Council of Turkey (TUBITAK; grant number:110K274) and Anadolu University Commission of Scientific Projects (BAP; grant number:1006E126).

a Assist. Prof. Aysun Colak (PhD), Department of Special Education, Faculty of Education, Anadolu University, Eskisehir, Turkey

Email: acolakdanadolu.edu.tr

b Gözde Tomris, Research Institute for Individuals with Disabilities, Anadolu University, Eskisehir, Turkey Email: gozdetomrisdanadolu.edu.tr

c Corresponding author

Prof. Ibrahim H. Diken (PhD), Research Institute for Individuals with Disabilities, Anadolu University, Eskisehir, Turkey

Research areas: Early intervention; Early childhood special education

Email: indikendanadolu.edu.tr

d Assist. Prof. Arzu Arıkan (PhD), Department of Primary Education Program in Preschool Education, Faculty of Education, Anadolu University, Eskisehir, Turkey

Email: arzuarikandanadolu.edu.tr

e Funda Aksoy (PhD), Department of Special Education, Faculty of Education, Anadolu University, Eskisehir, Turkey Email: fundabdanadolu.edu.tr

f Seçil Celik, Department of Special Education, Faculty of Education, Anadolu University, Eskisehir, Turkey Email: secilcelik2agmail.com 
Along with rapid growth and development in early childhood, some negative behaviors, including crying easily, shouting, raging and demonstrating unexpected reactions, might temporarily appear (Özbey \& Alisinanoğlu, 2009; Wakschlag et al., 2007). In addition, some other behaviors such as sleeping, eating problems, disobedience, extravagancy, lying, stubbornness, aggressiveness, timidity, fear, thumb-sucking, nail-biting, eating things like soil and lime, and avoidance of social environments can be encountered during the preschool period (Aydoğmuş, 2010; Yavuzer, 2011, 2012; Yörükoğlu, 2011). These behaviors might either be due to stress or they might be behaviors that disappear after the child learns what is appropriate behavior (Bailey, 2006). On the other hand, some behaviors that are accepted as a natural process of development might appear to be a more serious problem if they are repeated frequently (Bullis, Walker, \& Sprague, 2001; Keenan \& Wakschlag, 2002).

Antisocial behaviors, also known as problem behaviors, are considered important in this framework. Regarding the classification and definition of antisocial behaviors, various behaviors and definitions exist within the literature. Inappropriate behaviors, behavioral disorders, unwanted behaviors, disorderly behavior, disruptive behaviors, and undisciplined behaviors could be cited as examples of antisocial behaviors. Walker, Colvin, and Ramsey (1995) defined antisocial behaviors as repetitive and consistent refusals to engage in behaviors that are accepted by various forms of society (e.g., family, school, and the local community) and set by social rules. Antisocial behaviors can also be viewed as aggression and/or behaviors in the form of mischievous and negative reactions (as cited in Walker et al., 1998a; Walker, Severson, Feil, Stiller, \& Golly, 1998b).

Most of the studies on antisocial behaviors assert that they might be observed during early childhood, and must be approached meticulously (Bullis et al., 2001; Domenech-Llaberi et al., 2008; Keenan \& Wakschlag, 2002; Walker et al., 1998/a; Walker et al., 1998/b; Walker, Ramsey, \& Gresham, 2005). Principally, some studies point out that in cases when antisocial behaviors (emotional, social, and behavioral problems) are seen in little children who would be at risk and are not responded to promptly, this would increase the probability of academic failure, grade repetition, and dropping out of school (Davenport, Hegland, \& Melby, 2008; Webster-Stratton \& Reid, 2004).
The studies conducted in recent years reveal that antisocial behaviors among children and adolescents have increased gradually. This alarming trend has led to an increase in the number of studies focusing on the issue, and an acceptance of the issue as a national health matter by some countries in recent years.. Moreover, early intervention applications to antisocial behaviors are not only stated to be useful but also have an effective role in preventing the risk of antisocial behaviors that might appear in advance, or in decreasing this risk (Brown, 2007; Bullis et al., 2001; Davenport et al., 2008; Elliot, Prior, Merrigan, \& Ballinger, 2002; Walker et al., 2005). In this framework, various programs have been developed, applied and discussed in terms of effectiveness in preventing antisocial behaviors during early childhood (Anderson, 2007; Beard \& Sugai, 2004; Walker, Kavanagh, et al., 1998; Walker, Severson, Feil, Stiller, \& Golly, 1998; Webster-Stratton \& Reid, 2004; Webster-Stratton, Reid, \& Hammond, 2001; Webster-Stratton, Reid, \& Stoolmiller, 2008); Second Step (Grossman et al., 1997), First Step to Success (Walker, Kavanagh, et al., 1998), Incredible Years (Webster-Stratton, 2000) and First Step to Success Early Intervention Program (Walker et al., 1997) are shown among these programs.

Walker et al. (2005) stated that the early intervention programs developed to prevent antisocial behaviors should include three basic components and social factors that are related to those components: (i) home atmosphere and parents; (ii) class atmosphere and teachers; and (iii) playground and peers. Studies revealed that in terms of blocking antisocial behaviors in children, extensive prevention systems that included the child, family, school, and the society s/he was in, might provide effective results (Singer \& Wang, 2009; Sugai \& Horner, 2006; Walker et al., 2005). First Step to Success Early Intervention Program can be considered an example of extensive prevention systems developed for antisocial behaviors.

First Step to Success Early Intervention Program (Walker et al., 1997) is a program that was developed for preventing antisocial behaviors through some applications both at school and home context for children demonstrating or having a risk to demonstrate antisocial behaviors in both contexts. The main goal of the program is to teach the children to develop positive and accommodating relationships with both classmates and the teacher. The program comprises both the home and school environment of the child with parents, teacher and an implementing counselor working 
in collaboration during the application process of the program. The program has three compatible dynamic modules: (i) Screening/Diagnosis Module, (ii) Class Module, and (iii) Home Module.

Children with antisocial behaviors are identified through Teacher Opinion Scales and Multi-stage Evaluation Tools, including teacher opinion and detailed observations, during the Screening/Diagnosis Module. The Class Module is aimed to have children acquire positive behaviors rather than controlling antisocial behaviors in a classroom medium. Based on this goal, a teacher provides visual feedback to a child related to his or her behavior with a card on which one side is RED and the other side GREEN. As the child demonstrates appropriate behaviors, the GREEN side of the card is shown; if the behaviors are inappropriate, the RED side of the card is shown. Appropriate behaviors are recorded in predetermined periods in the program, and provided that the determined score is reached, the child would be awarded, along with the whole class. The Class Module of the program lasts for 30 successful school days. The program is applied in certain durations in the classroom each school day. At the beginning, this duration is determined as 20 minutes whereas it is extended to a whole day after the $16^{\text {th }}$ day. The Home Module is applied after the $11^{\text {th }}$ day of the Class Module. Later on, this module is applied simultaneously with the Class Module for six weeks in the following process. This module consists of activities/games that are completed together by the child and parents for 15-20 minutes on a daily basis.

First Step to Success Early Intervention Program was adapted to the Turkish language and culture by Diken, Cavkaytar, Batu, Bozkurt, and Kurtyılmaz (2008) as First Step to Success Early Intervention Program. In Turkey, First Step to Success has been applied in kindergarten and primary school classes, and positive effects from the program on antisocial behaviors and social skills have been found (Çelik, 2012; Diken, Cavkaytar, Batu, Bozkurt, \& Kurtyılmaz, 2010, 2011). Other studies in international and national literature have evaluated the efficiency of First Step to Success Early Intervention Program from various aspects. The program was applied to children coming from different ethnic backgrounds (Diken \& Rutherford, 2005); to diagnosed children (Özdemir, 2011; Seeley et al., 2009); and to twin students (Golly, Sprague, Walker, Beard, \& Gorham, 2000). Studies investigating the efficiency of the program on different skills found out that the program improved academic skills (Sumi et al., 2012; Walker et al., 2009; Walker, Kavanagh, et al., 1998); social skills (Diken \& Rutherford, 2004; Diken,
Cavkaytar, et al., 2011; Diken et al., 2010, Sumi et al., 2012; Walker et al., 2009); and increased the participation duration in academic activities (LienThorne \& Kamps, 2005; Russell-Carter \& Horner, 2007, 2009). In addition, there are studies that have found out the program's positive contributions to teachers (Blalock, 2008; Sprague \& Perkins, 2009) and other students (Sprague \& Perkins, 2009). Most of the studies that were reviewed were conducted through single subject (Beard \& Sugai, 2004; Golly et al., 2000; Lien-Thorne \& Kamps, 2005; Özdemir, 2011; Rodriguez, Sheldon, Loman, \& Horner, 2009; Russell-Carter \& Horner, 2007, 2009; Sprague \& Perkins, 2009) and experimental research designs (Diken, Cavkaytar, et al., 2011; Diken et al., 2010; Seeley et al., 2009; Sumi et al., 2012; Walker et al., 2009; Walker, Kavanagh, et al., 1998). However, a number of the studies using qualitative data collection techniques and describing the views of people who have a key role in the application of the program, including program counselors, teachers, and family, are limited (Diken \& Rutherford, 2005; Overton, McKenzie, King, \& Osborne, 2002).

Principally, the studies that focus on deep perceptions with scientific justifications of some applications are suggested to provide significant contributions to the field. Odom et al. (2005) focused on the necessity of working on an effective implementation through a holistic perspective. In this framework, qualitative studies are stated to be promising in terms of demonstrating how an application works and providing detailed information about the program (Gersten, Baker, \& Lloyd, 2000; Odom et al., 2005). In light of this information, the present study aims to describe the views of teachers, parents, and FSS-PSV counselors in terms of the Preschool Version of First Step to Success Program, the efficiency of which was proven through various studies, the implementation of the program, and the contributions it provided. The study provides a significant contribution to the field by including detailed views from teachers, parents, and counselors on a scientifically-based program implementation.

\section{Method}

\section{Research Model}

The scope of this project was conducted under the support of TÜBİTAK (The Scientific and Technological Research Council of Turkey) and Anadolu University Scientific Research Commission. This study represents the qualitative aspect of a more comprehensive, mixed design 
research project and was conducted between October 2010 and October 2012. First Step to Success Early Intervention Program was implemented as the pilot and the main study in two stages at public preschools. The views of teachers, parents, and program counselors on the First Step to Success Early Intervention Program were collected through a qualitative data collection procedure at the main stage of this project.

First Step to Success as developed by Walker et al. (1997) was first adapted to Turkish by Diken, Cavkaytar, Batu, Bozkurt, and Kurtyılmaz (2008) and called First Step to Success Early Intervention Program Turkish Version (FSS-TV). The effectiveness of FSS-TV on kindergarten, first grade, and second grade students was tested through a pilot and main study. Later, the version of FSS that was adapted for preschool students by Walker et al. (2005) was also adapted to Turkish by Diken, Bozkurt et al. (2011), and was called First Step to Success Early Intervention Program Preschool Version (FSS-PSV).

\section{Data Collection Tools}

Qualitative data collection techniques, semistructured interviews, researcher diaries, and field notes were used in the study in order to best describe the views of teachers, parents, and program counselors on FSS-PSV implementation. Interview questions for the semi-structured interviews were prepared during the piloting stage by the project team, and preliminary interviews were conducted with participants. The interviews and the questions asked during the interviews were reevaluated after the piloting by the project team and two experts. As a result of the reevaluation, some changes were made, and the interview questions were finalized for main study stage.

Data collection tools prior to the implementation of the FSS-PSV consisted of the Personal Information Form that obtained demographic information about the participants and interview forms that included 13 questions for teachers and 20 for parents. Postimplementation data collection tools included: interview forms that had 11 questions for teachers, interview forms that had 11 questions for parents, and interview forms that had nine questions for counselors . In total, five different interview forms were prepared for the study. Two of the forms were used with teachers and parents before the implementation of the program, and three forms were used with teachers, parents, and counselors after the implementation of the program.

\section{Participants of the Study}

The study was conducted at six preschools in the boundaries of Eskisehir Metropolitan Municipality. Of these preschools, five were public schools under the auspices of Ministry of National Education, and one was under the jurisdiction of Eskisehir Metropolitan Municipality. Initially the authorized person in each school was contacted, and they were informed about the aim of the study. Meetings were organized with the volunteer teachers who thought that there were students demonstrating antisocial behaviors in their classes. The FSS-PSV program was explained in detail to the teachers in these meetings.

A total of 11 teachers voluntarily participated in the study. All of the teachers who participated in the study were female. None of the teachers had participated in any program that aimed to change antisocial behaviors in the past. The ages of the teachers were between 25 and 45, and all of them were university graduates. One of the teachers was an elementary school teaching department graduate, and all the others were preschool teaching department graduates. Having identified the teachers, target students and parents of the study were identified as well. In the process of identifying the parents, they were informed about the FSS-PSV program, the aim of the study, and their permissions were obtained. The number of parents who participated in the study differs in the pre-implementation and post-implementation stages. Since both parents and grandparents came to the interviews together, both mother and father or grandmother and grandfather were also included in the interviews. Thus, the pre-implementation participants of the study were 10 mothers, one father, one grandfather and one grandmother, a cumulative number of which was 13. There were 11 voluntary participants in the post-implementation interviews, 10 of whom were mothers and one grandmother. The youngest of the parent participants was 28 years old, and the oldest was 55 years old. Educational achievements differed, ranging from primary school graduates and university graduates. Six of the mothers who participated in the study were working-mothers. As for the grandmother, she was retired and was not working anywhere.

An interview with six FSS-PSV counselors was organized after the implementation process of the program. An FSS-PSV counselor is the key person in the success of the application and the achievement of the goals of the program. Responsibilities of FSS-PSV counselors included informing teachers and parents about the program, conducting the 
screening process, deciding on which child needs the program in collaboration with the teacher, getting permission from parents for the child to participate in the program, cooperating with teachers, providing the implementation of class and home modules as indicated in the program, and considering the problematic aspects during the implementation and suggesting solutions for them. Six FSS-PSV counselors, one for each school, were designated in the study. All of the FSS-PSV counselors accepted the identified responsibilities and participated in the study voluntarily. FSS-PSV counselors at the implementation sites included one school principal, three assistant principals, and two school counselors. Ages of the FSS-PSV counselors ranged from 28 and 37. All of the FSSPSV counselors were female; the assistant principal and principal had teaching experience in preschool education. As for the school counselors, they had worked at elementary schools in their previous professional careers, and it was their first year in the preschool education field.

\section{Data Collection}

Semi-structured interviews with the study participants were conducted in two stages: (1) before the implementation of the FSS-PSV program, and (2) after the implementation of the FSS-PSV program. Teachers and parents were interviewed before the implementation, and teachers, parents, and FSS-PSV counselors were interviewed after the implementation was concluded. All of the interviews were recorded through a digital voice recorder, and after which the recordings were all transcribed and printed. Digital records of the interviews were transcribed without any modifications. Interviews were conducted at the meeting rooms of the schools in accordance with the availability of the participants. Before each interview, participants were given the Interview Guide describing what the aim of the study was, who sponsored the research, what the FSS-PSV program was, how the study would be conducted, and why the interviews would be recorded. All the participants signed a Contract Form stating that they participated in the study voluntarily, and let the interview be recorded. The interviews prior to the implementation of the FSSPSV program started with having participants fill in the Personal Information Form aimed to gain demographic information about the participants. Having completed the interviews prior to the program, FSS-PSV implementation started at the preschools. The program lasted for six weeks, and after the completion of the program, post-program interviews were conducted.

\section{Data Analysis and Reliability Study}

Descriptive analysis technique was used to analyze the interview data. For quantitative analysis of the data, frequencies were also calculated. The data were examined under five groups as shown in Table 1. Abbreviations for interviews in each group are also shown in parenthesis in the table.

\begin{tabular}{lc}
\hline $\begin{array}{l}\text { Table } 1 \\
\text { Grouping the Interview Data }\end{array}$ & $\begin{array}{l}\text { Number of the } \\
\text { participants }\end{array}$ \\
\hline Groups Interviewed & 11 \\
\hline 1. Group: Pre-program Teacher - (PpT) & 11 \\
2. Group: Pre-program Parent - (PpP) & 11 \\
3. Group: Post-program Teacher - (PopT) & 11 \\
4. Group: Post-program Parent - (PopP) & 6 \\
5. Group: Post-program FSS-PSV & 50 \\
\hline \multicolumn{2}{l}{ Counselors - (PopC) }
\end{tabular}

The interview recordings were transcribed and interview forms that included the transcribed data were created. All transcriptions were checked again by listening to the interview recordings and every interview form was read in detail to prevent data loss; two independent researchers conducted this process. During the analysis process, each interview form included information about the interview date, interviewee, interviewer, and duration of the interview. Using each interview question, each answer to these questions, and classifications inform the literature, main themes and sub-themes were identified in the interview forms. This way it became possible to match the data with the main and subthemes. Each researcher developed an interview codebook, independently, for each group of interviews. Later on, the researchers came together, and revised the categories and overlapping themes in the codebooks. Concerning issues of disagreement about themes, researchers discussed these themes and related the theme to a more suitable one after negotiations. After coding the data with themes, the views of participants were classified. Sub-themes that were developed under the main themes based on the interview questions in the previous step were revised. Having confirmed the themes and sub-themes, data were regularized and finalized. During the coding process, views of the participants coded under certain themes were demonstrated numerically in frequencies and which one these opinions would be directly quoted was also identified. This way, 
connections among the opinions stated by the participants were determined. Having completed all those processes, analyses were completed and findings of the study were written.

In the framework of inter-rater reliability, five interview forms that included all of the interview forms of four groups were chosen through an unbiased sampling method to examine. The reason for examining five interview forms was the fact that five people in the group was equivalent to more than $30 \%$ of the total participants, which was 11 . As for the interview forms in the fifth group (Post-program counselors), there were six interview forms, and they were all examined. A total of 26 interview forms and five Interview Codebooks developed for each group were reproduced and given to two experts in the field. Selected interview forms were evaluated by these two experts according to the Interview Codebook independently. Completing the evaluation process, the two experts came together and compared the interview forms of each group individually. Findings that were derived from the comparisons of the two experts were compared to the findings of the researcher (second author) in the following process. During the comparisons, each category that was marked by the experts was controlled and marked as inter-rater Agreement and Disagreement. If the experts marked the answer of a question in the same way, this was accepted as Inter-rater Agreement; however, if there was a difference in the marking of the experts, the analysis of the researcher (second author) was taken as reference, and it was accepted as Inter-rater Disagreement. Moreover, if one of the experts marked the frequency and the other did not do any marking, this was accepted as Interrater Disagreement, too. In conclusion, reliability calculations were made on the basis of [Agreement/ (Agreement + Disagreement)] X 100 formula. As a result of the inter-rater reliability study conducted on five groups, the reliability average score of $1^{\text {st }}$ Group (Pre-program Teacher) was found to be $94 \% ; 2^{\text {nd }}$ Group (Post-program Teacher) was 94\%; $3^{\text {rd }}$ Group (Pre-program Parent) was $94 \%$ as well; $4^{\text {th }}$ Group (Post-program Parent) was 95\%; and $5^{\text {th }}$ Group (Post-program Counselors) was 97\%.

\section{Credibility, Transferability, Coherency, and Confirmability}

In order to increase credibility (internal validity) in the study, the researchers visited the schools once a week during the implementation of FSSPSV program, observed the class/classes that participated in the study for at least 30 minutes during those visits, and recorded the information and observations they gathered in research diaries regularly. The information gathered from those visits is discussed in the findings and discussion section. Triangulation of the data sources was ensured by obtaining data from different groups including, teachers, parents, and counselors. In order to ensure the transferability (external validity) of the study, the research model, data resources, data collection tools, data collection procedure, analysis and interpretation of the data, and how the findings were arranged are described in detail.

In order to increase the coherency (internal reliability) of the study, outside researchers were included in the study. Preparation of the codebooks in the data analysis process was pursued in cooperation with experts, and the data were verified with the experts. Either positive or negative, all of the findings were included in the study. Quotes from all data sources were used in great sensitivity without adding any interpretation to the original data. Findings derived from the data were reported by associating with each other and literature. In order to provide confirmability (external reliability) for the study and thus prevent data loss, digital voice recording were checked against transcripts and printed transcriptions were read again for verification. All the collected data were compiled by classifying them in categories and data were filed in a systematic way.

\section{Findings}

\section{Findings on Interviews with Teachers Prior to the Program}

Students' Antisocial Behaviors Participated in FSSPSV: Examining the studies conducted on antisocial behaviors, it could be seen that the antisocial behaviors were classified in various forms (Cameron, 1998; Martin, Linfoot, \& Stephenson, 1999). Classifications that were made in literature were taken into account in this study, and a classification was made based on this framework. Based on studies conducted by Hamlett (2007), Tremblay (2012), and Domenech-Llaberia et al. (2008) offensive behaviors were classified as physical attack and verbal attack. Behaviors such as hitting, pushing, choking peers, damaging goods by beating or breaking, bursting with anger and shouting, overreaction and screaming, fighting with peers, and biting were coded under the physical attack theme. Descriptions made by Çifçi and Sucuoğlu (2010) and Ergenekon (2012) on social skills and inadequacy in social skills of children were taken into consideration in the study. Teachers that noted behaviors in children 
such as telling their requests by crying, interrupting their friends, not listening to others, not making eye contact, not being able to fulfill an assigned duty, not sharing, jealousy, lying, not participating in activities, and talking without permission were all collected under the code of inadequacy in social skills.

\begin{tabular}{lc}
\hline Table 2 & \\
Students' Antisocial Behaviors Participated in FSS-PSV from \\
the Perspectives of Teachers
\end{tabular}

Some of the teachers stated during the interviews that the students they chose for the program would demonstrate more than one antisocial behavior. All of the behaviors identified by the teacher were regarded in this situation and antisocial behaviors were collected under five codes. Table 2 shows the antisocial behaviors of the students chosen by teachers; physical attacks and inadequacy in social skills were demonstrated at excessive levels in the children. In addition, teachers stated that they observed obsessive behaviors (whirling around, a constant desire for being in the first rank) and attention deficiency among the students who participated in the program. Their statements relate to this situation as

"My student called [...] is a child who always responds in violence when he is angry about something. He can obviously shows his rage when he gets angry. Whenever you don't do something he wanted, he absolutely takes his revenge. He demonstrates behaviors such as pushing a child without anyone noticing." [Preprogram interview with teacher-PpT3]

"He never attends to his own properties. I was even astonished with this situation at the beginning. He has been attending to preschool for two or three years. He should have gained at least this behavior. He is leaving his goods, not protecting them. For example, he is not closing the cap of his Pritt. Yesterday once again he left all his watercolors, brushes, and other stuff around." [PpT11]

Findings delivered from the pre-program interviews with teachers showed that the antisocial behaviors of students who participated in the FSSPSV Program were mostly observed in the physical attack and inadequacy in social skills categories, and other behaviors such as attention deficit were less frequently observed.

Reasons of Students' Antisocial Behaviors for Teachers: As seen in Table 3, family-related reasons stood out compared to others reasons for antisocial behaviors in students as observed by teachers.

\begin{tabular}{lc}
\hline Table 3 & \\
Reasons of Antisocial Behaviors of Students for Teachers & \\
\hline Categories & $f$ \\
\hline Family-related reasons & 9 \\
Child-related reasons & 4 \\
Teacher-related reasons & 2 \\
I have no idea & 2 \\
\hline Total Views & 17 \\
\hline
\end{tabular}

Such reasons as poor parent attitudes, careless parents, quarrels between parents, divorced parents, incarcerated parent, overworking parents, grandparents' looking after the child and their inconsistent behaviors, death of grandparent were expressed by teachers for the antisocial behaviors exhibited by the students who participated in the study and these were gathered under family-based reasons theme.

Teacher opinions related to this situation noted:

"Inconsistent behaviors of mother and father [...] as far as I observed, father is freer than mother, mother is more disciplined, authoritarian [...] Mother wants to shape the child too much." [PpT2]

"Education he got from family [...] it is because of the rules and behavioral education he got from family. He can have whatever he wanted done at home, and behaves thinking that he can do the same at school. Unfortunately, as soon as he understands that this is impossible at school, he shows problematic behaviors." [PpT4]

"Here, there are quarrels and problems between father and mother. Family always has economic problems. Actually such problems stem from family." [PpT8]

According to teachers, findings related to the reasons for antisocial behaviors show that familybased reasons are among the first factors that caused antisocial behaviors while teacher or child-based reasons were among the least frequent ones. "...I remember thinking for the answer to this question in my mind during the interviews; I wonder if there is a teacher who reflects on him/herself and looks for the reasons of a problem s/he encountered in him or herself." (Researcher diary; 04.12.2012; p. 3). Remarkably, as it is stated in the section of interviews with parents, parents also thought that antisocial behaviors came from family. 
Methods/Techniques Used by Teachers against Antisocial Behaviors: Based on the answers from the teachers regarding the techniques or methods they used when they faced antisocial behaviors in the class, it can be understood that they used more than one technique or method together.

Table 4

Methods/Techniques Used by Teachers against Antisocial Behaviors

\begin{tabular}{lc}
\hline Categories & $f$ \\
\hline Talking to students about the behavior & 7 \\
In-class and out-of class break technique & 6 \\
Rewarding the positive behaviors & 5 \\
Talking to the families & 3 \\
Ignoring & 2 \\
\hline Total Views & 23 \\
\hline
\end{tabular}

As seen in Table 4, talking to students about the behavior, in-class and out-of class break technique and awarding the positive behaviors were the most frequently preferred methods, among the techniques/ methods used by teachers. Some teachers stated their opinions on this situation as follows:

"At first I am talking to the child [...] one-on one, actually. I talk to him if the behavior is proper or not. For example, if there is a positive behavior, I appraise and reinforce it, but this doesn't always happen. We cannot see this always as the child might not show any positive behavior." [PpT11]

"Well, ignoring once or twice. As this becomes more frequent, maybe I can take him away for a while, for a break [...] actually this is not dismissing him from the activity, but getting him to have a rest; to reflect on his behavior." [PpT5]

Pre-program interview findings of the study revealed that the teachers used techniques such as talking to the student on his/her behavior and inclass and out-of class-breaks frequently. In addition to this, rewarding positive behaviors, talking to families, and ignoring were relatively less frequent techniques used by teachers.

Teachers' Support Needs Regarding Antisocial Behaviors: Examining Table 5, it can be seen that the support the teachers needed in working against antisocial behaviors frequently involved professional help and effective programs toward preventing antisocial behaviors.
Table 5

Support the Teachers Needed Regarding Antisocial Behaviors

\begin{tabular}{ll}
\hline Categories & $f$ \\
\hline Professional help & 7 \\
Learning effective programs toward preventing & \\
antisocial behaviors & 7 \\
Parenting education toward families & 3 \\
Family-teacher collaboration & 2 \\
Regulations at school environment & 2 \\
Co-teacher support & 1 \\
\hline Total Views & 22 \\
\hline
\end{tabular}

Regarding this, some teachers stated their views as

"For example an expert; especially a psychological counselor [...] As he knows how to deal with those behaviors in detail, he can go deeper into these behaviors and find the underlying reasons, I think. Or how can the behaviors be solved after finding the underlying reasons [...] actually, we try to do something, but we are not sure whether we do something right or wrong..." [PpT2]

"In addition to this, I would like to learn some special programs that support the positive behaviors of children, programs that minimize negative behaviors." [PpT4]

Based on the findings, it can be seen that the teachers need professional help and support in learning effective programs to deal with antisocial behaviors. The teachers' statements show that issues within categories such as parenting education toward families, family-teacher collaboration, regulations in the school environment, and coteacher support occur less frequently.

\section{Findings on Interviews with Parents Prior to the Program}

Antisocial Behaviors of Children from the Perspectives of Parents: As seen in Table 6, views from the parents were gathered under the five themes indicated in the table. Regarding the antisocial behaviors of their children, parents focused on their children's objection to their directions at home, disobedience, to much of a desire for watching TV, crying after not achieving the desired thing, being overly stubborn, and resisting homework.

\begin{tabular}{lc}
\hline Table 6 \\
Antisocial Behaviors of Children From the Perspectives of \\
Parents
\end{tabular}


Thereupon, the behaviors stated by parents were compiled under the inappropriate behaviors theme. While inappropriate behaviors by family was the most frequent theme, the less frequent themes were hyperactivity, attention deficiency, physical aggression, and dependence to mother. Some parents expressed the following opinions regarding the antisocial behaviors they observed in their children:

"Now, when I get him dressed, I always have to warn him to turn to me, to look at me, he always engages with other things, pays attention to other things [...] wear your shoes, do this, do that [...] I always have to warn him to do something..." [Parents Pre-program Interview-PpP2]

"Where ever there is a harmful thing, he plays with it. Whenever I say, "don't do that," or not do what he wants, he overreacts, pushes me around; that is, he is getting ill-tempered. Trying to beat, smack, and even bite me. He cries too much in the sleep. Terribly he cries..." [PpP7]

The interviews with parents imply that the behaviors of children seem to be influenced by some factors such as the socio-economic condition and educational background of family. A researcher made the following statements in a research diary regarding this situation:

"...I think the life conditions the children are in effect their behaviors. Today the interview I did with mothers at this school (it was a school, students of which were mainly children of lower socio-economic level families in the ghettos of the city where the study was conducted) affected me deeply. I wondered, if those children had a different life, how would it be?" (Researcher Diary, 01.03.2012, p. 25).

Views of Parents on Reasons of Antisocial Behaviors of their Children: Analyzing Table 7, it can be seen that most of the parents stated that the antisocial behaviors their children exhibited at home stemmed from family-related reasons.

\begin{tabular}{lc}
\hline Table 7 & \\
Views of Parents on Reasons of Antisocial Behaviors of their \\
Children \\
\hline Categories & $f$ \\
\hline Family-related reasons & 10 \\
Child-related reasons & 5 \\
Caretaker-related reasons & 1 \\
No idea & 1 \\
\hline Total Views & 17 \\
\hline
\end{tabular}

Some parents gave the following opinions on the antisocial behaviors of their children:
"He became depressed because of an event we lived last year. Our house caught fire in front of all our eyes. Moreover, my husband locked himself in and burned himself. He saw both his father and house burning. He was affected from this a lot, I think." [PpP8]

"Well, as he was the only child in family, at the beginning, whatever he wanted was done. This might be the reason. And I think it is a little bit genetic. Because he was very clear about the things he didn't want even when he was just 1-2 months old. For example, if he didn't want us to touch him, he was pushing our hands away. That is, he is a determined child on his demands." [PpP4]

After reviewing the findings, it can be seen that the parents focused on family-related reasons more in terms of reasons of antisocial behaviors of their children, which is similar to the views of the teachers. Child and caretaker related reasons were mentioned less frequently.

Methods/Techniques Used by Parents against Antisocial Behaviors of their Children: As is demonstrated in Table 8, parents frequently tried to correct the antisocial behaviors they faced with their children by talking to them; they used punishment as a solution method to try and induce second order change. Ignoring, distracting, rewarding, and reacting with a raised voice were emphasized less frequently.

\begin{tabular}{lc}
\hline Table 8 & \\
$\begin{array}{l}\text { Methods/Techniques Used } \\
\text { Behaviors of their Children }\end{array}$ & Parents against \\
\hline Categories & \\
\hline Talking to child & 8 \\
Punishing & 5 \\
Ignoring & 4 \\
Distracting & 3 \\
Rewarding & 3 \\
Reacting with a raised voice & 2 \\
\hline Total Views & 25 \\
\hline
\end{tabular}

One parent stated her opinion on this situation as

"At first, I tell him that what he is doing is wrong. Then, if he is playing with a toy, I am taking it away, that is, I don't let him do something he likes doing, or I don't do what he likes. For example, say, cake. I don't bake a cake for him." [PpP10]

Support the Parents Needed against Antisocial Behaviors of their Children: As seen in Table 9, a high majority of parents stated that they wanted to participate in parenting education programs that would be particularly helpful in focusing on raising children and overcoming antisocial behaviors. 
Table 9

Support the Parents Needed Against Antisocial Behaviors of their Children

\begin{tabular}{ll}
\hline Categories & $f$ \\
\hline Parenting education & 8 \\
Getting psychological support & 1 \\
Assessment of their children with reliable and & 1 \\
valid instruments & 1 \\
Participating in systematic and scientifically- & 1 \\
proven programs & \\
Don't need support & 12 \\
\hline Total Views
\end{tabular}

One parent stated:

"I want antisocial behaviors of my child to be observed, want to be given support for me and my child, and want to learn what I can do through trainings." [PpP8]

\section{Post-Program Findings on Interviews with Teachers}

Views of Teachers on Effects of FSS-PSV Program on Antisocial Behaviors of Students: Table 10 is about the effects of the FSS-PSV program on the students; it can be seen that the teachers thought that the program had the most positive effects on the improvement of social skills. In addition, they also stated that the program was effective in terms of decrease in aggressive behaviors. However, some teachers stated that the program did not have any effect on students. This may be related to the extra effort that the program participation requires from the teachers whose attitudes changed after the program started. Regarding this issue, the researcher indicated, "We really worked well with the teachers who were enthusiastic and curious. However, some teachers who were very enthusiastic at the beginning, but later on thinking that the program was overburdening, lost their hopes after a while." (Researcher diary, 25.05.2012, p. 40).

\begin{tabular}{lc}
\hline Table 10 \\
Views of Teachers on Effects of FSS-PSV Program on Antisocial \\
Behaviors of Students \\
\hline Categories & $f$ \\
\hline Improvement in social skills & 8 \\
Decrease in aggressive behaviors & 5 \\
No effect on student behaviors & 3 \\
\hline Total Views & 16
\end{tabular}

In regard to the effects of the FSS-PSV program on the antisocial behaviors of students, some teachers stated:

"I can give an example. For example, a student said, 'teacher, [...] was not playing with us before, he was not letting us play. Now, he lets. Yes, [...] is a good child from now on', that is, within their words, I say this. I know they expressed like this." [Teachers post-program interview-PopT2]

"I don't observe harming behaviors anymore. In fact he was beating occasionally, but I observe a decrease in it as well. I can say that the child became more stable." [PopT7]

"How did it affect? I think it did not affect too much. $\mathrm{He}$ is the same. $\mathrm{He}$ is a little bit better during the game. But as soon as the game finished he turned back to himself and got more ill-tempered." [PopT9]

\section{Contribution of FSS-PSV Program to Teachers:}

As is seen in Table 11, in terms of contributions the program made for the teachers, as the teachers noted being systematic and programmed, and gaining effective time management skills. The teachers also stated that the program contributed positively in terms of their focusing skills for positive behaviors with students more, skills of being consistent and determined against antisocial behaviors, gaining a different perspective, learning a new method, using verbal reinforcement, and using a concrete material (red-green cards).

\begin{tabular}{ll}
\hline Table 11 & \\
Contribution of FSS-PSV Program to Teachers & $f$ \\
\hline Categories & \\
\hline $\begin{array}{l}\text { Gaining skills of being systematic, programmed, and } \\
\text { effective time management }\end{array}$ & 7 \\
$\begin{array}{l}\text { Gaining focusing skills on positive behaviors of students } \\
\text { Noticing the advantage of using a concrete material }\end{array}$ & 3 \\
(red-green cards) & 3 \\
$\begin{array}{l}\text { Gaining skills of being consistent and determined } \\
\text { against antisocial behaviors }\end{array}$ & 2 \\
Gaining a different perspective, learning a new method & 1 \\
Gaining skills of using verbal reinforcement & 1 \\
\hline Total Views & 17 \\
\hline
\end{tabular}

With respect to these findings, two teachers stated their opinions as

"This FSS-PSV study forces teacher to be more planned. Yes, you are planned, you will conduct a study. There is a time allocated for this study, and there is a score the child has to get at the end of the study. And there is an award as well. And you, as the conductor of this study, come to school more organized and planned in order not to miss anything in the study and have it reach its aim.” [PopT5]

"What can I say as a teacher? Well, frankly speaking I wasn't used to use praises in my lessons. Now with the effect of the program, I have started to use verbal praises. Not only to [...]; to all my students. Actually, I used to think that it didn't have much effect, verbal praise. There are many expensive toys here, but they 
don't make them happy. I was thinking like this but my thoughts have all changed, really. I can say they all disappeared. Because I noticed that they can be happy with some very little things, say, such as a small sticker." [PopT2]

\section{Post-Program Findings on Interviews with Parents}

Views of Parents on Effects of FSS-PSV Program on Children's Antisocial Behaviors: In Table 12, it can be seen that most of the parents stated that the program was effective in terms of a decrease in inappropriate behaviors for their children, and they stated that their children had demonstrated changes in their behaviors. Moreover, two parents stated that the program was effective in terms of a decrease in physically aggressive behaviors in their children.

\begin{tabular}{lc}
\hline Table 12 \\
$\begin{array}{l}\text { Views of Parents on Effects of FSS-PSV Program on Children's } \\
\text { Antisocial Behaviors }\end{array}$ \\
\hline Categories & $f$ \\
\hline Decrease in inappropriate behaviors & 9 \\
Decrease in physically aggressive behaviors & 2 \\
\hline Total Views & 11 \\
\hline
\end{tabular}

Two parents stated their opinions as

"What gripped my attention is [...] At first, when he took that green card after a success he was very positive at home, if the color of the card changed into white or to negative card, he was trying to find a reason for that [...] Apart from that we had differences in our exchanges at home. For example, he says that it is important to enjoy while playing; not to win. Sometimes I might not win. Before the program, if he couldn't win or if he wasn't the first, or if he wasn't at the first rank, it would be a problem. Now he has realized this." [Parents post-program interview-PopP4]

"At first when I told him not to do something, he used to get angry and try to bite my hand. Now that I learned to play with him at home [...], he started to behave as a child. In the past he was behaving as an adult and getting angry, he couldn't understand the reason. But now, he behaves as a child." [PopP7]

Effect of FSS-PSV Program on Families from the Perspectives of Parents: As Table 13 reveals, the program had positive influences on families in areas of providing contributions to passing time together with family members, and changing the attitudes of family positively toward the child. However, one of the parents stated that the program did not make any contribution to their family.

\begin{tabular}{lc}
\hline Table 13 \\
$\begin{array}{lc}\text { Effect of FSS-PSV Program on Families from the Perspectives } \\
\text { of Parents }\end{array}$ \\
\hline Categories & $f$ \\
\hline Contributions in spending time together with family & \\
members & 6 \\
Changing the attitudes of family positively toward the & \\
child & 6 \\
No contribution of the program to the family & 1 \\
\hline Total Views & 13 \\
\hline
\end{tabular}

Regarding the effects of the FSS-PSV program on families, some parents stated:

"Firstly, I like training cards a lot. They include practical knowledge as well. Moreover, the games are wonderful. Normally, they are the games that we should play with our children every time. And they give you an idea about games. So, you are spending more quality time. Because you don't know what to do. You know a few standard things. In addition, the thing that made me the happiest in this program was that his teacher made a tree. I saw it from the outside. They wrote what children said on it. They wrote, 'My mother is a wonderful mother because we play wonderful games with her, for my son, Ege." [PopP5]

"I have learned that there were many thing that I didn't know; I was doing wrong. I have learned that. At least, I have learned how to talk to my child." [PopP2]

Post-Program Findings on Interviews with FSSPSV Counselors

Views of FSS-PSV Counselors on the Effect of the Program in Changing Antisocial Behaviors of Students: As is seen in Table 14, all of the FSS-PSV counselors stated that the program was effective in changing antisocial behaviors of students.

\begin{tabular}{lc}
\hline Table 14 \\
Effect of the Program in Changing Antisocial Behaviors of \\
Students for FSS-PSV Counselors \\
\hline Categories & $f$ \\
\hline Effect in changing antisocial behaviors of students & 6 \\
\hline Total Views & 6 \\
\hline
\end{tabular}

One of FSS-PSV counselors stated their ideas with respect to this as

"At first, I had some hesitations whether the program would be useful or not. Because there were some students with serious behavioral disorders. There were some with more than one behavioral disorders. I think the program had positive effects even on them. Positive changes are a lot." [Counselor, post-program interview-PopC2] 
Views of FSS-PSV Counselors on the Effect of the Program on Teachers: As is indicated in Table 15, the FSS-PSV counselors had varying opinions on the effects of the program on teachers. FSS-PSV counselors stated that the program had positive contributions to professional development of teachers; helped teachers in terms of coping with antisocial behaviors and pursuing class activities; caused overburden on teacher; and caused teacher to focus on just one student.

\begin{tabular}{lr}
\hline Table 15 & \\
Views of FSS-PSV Counselors on the Effect of the Program on \\
Teachers & $f$ \\
\hline Categories & 3 \\
\hline Positive contributions to professional development of & \\
teachers & \\
Coping with antisocial behaviors and pursuing class & 2 \\
activities & 1 \\
Overburden on teacher & 1 \\
\hline Caused teacher to focus on just one student. & 7 \\
\hline Total Views & \\
\hline
\end{tabular}

An FSS-PSV counselor stated her ideas as

"At first, the teachers were afraid too much about whether they could manage it, whether it would spoil their routines; or it would affect their activities. They worried. However, using the program as a tool that eased their activities, they realized that it facilitated them to continue the rest of the activity. And they experienced a new implementation. We realized that the program didn't disrupt their routines as well." [PopC4]

Views of FSS-PSV Counselors on the effect of the Program on Families: With regards to the effect of the program on families, the majority of the FSSPSV counselors referred to positive results. They stated that the program made the families happy as they observed positive changes in their children as shown in Table 16.

\begin{tabular}{ll}
\hline Table 16 & \\
Views of FSS-PSV Counselors on the Effect of the Program on \\
Families & $f$ \\
\hline Categories & 4 \\
\hline Being happy with positive changes in their children & 2 \\
Increasing communication between family and the child & 2 \\
Strengthening the school-family cooperation & 1 \\
Becoming informed about how to cope with antisocial & \\
behaviors & 1 \\
\hline Total Views & 8 \\
\hline
\end{tabular}

Some FSS-PSV counselors' opinions demonstrate the program's positive effects on families:

“... Mother is happier. At least when he comes to school. Her stating that she was not hearing any complaints, her coming to the school enthusiastically, and her stating that she was coming to school happily was a positive feedback for us." [PopC2]

"I think families have increased their communication with their children, or here at school, I mean, either family-school cooperation, or family-teacher meetings, they all increased. Family was affected from this side." [PopC1]

\section{Discussion}

In this section, the findings of the study in regards to the research questions are discussed, both within itself and in light of existing studies in the literature.

Based on the findings obtained in this study, most of the teachers before the program encountered physically aggressive behaviors from the children who participated in the study. When previous studies related to the FFS program are examined (Beard \& Sugai, 2004; Golly et al., 2000; RussellCarter \& Horner, 2007; Walker, Kavanagh, et al., 1998), children's antisocial behaviors that were observed in the context of those studies appear to be parallel to the antisocial behaviors observed in the children who participated in the present study. For instance, Golly et al. (2000), found in their study on the effectiveness of FSS that the target children demonstrated such behaviors as aggressiveness, objection, not participating in activities, walking in the class, disturbing friends by touching, and harming goods. Similarly, Hamlett (2007) also claims that the most common types of behavior that might be observed in preschool children are physical and verbal aggression. DomenechLlaberia et al. (2008) examined the aggressive behaviors of children with their peers during early childhood from the perspectives of teachers. The study stated, teachers, frequently encountered physically aggressive behaviors among other behaviors that was classified under four categories (physical, verbal, against the objects, and symbolic aggression). Hammarberg and Hagekull (2002) also discovered that externalized aggressive behaviors (beating, pushing, harming goods and so on) were among the behaviors that troubled teachers the most and that were difficult to control.

In the present study, parents also described antisocial behaviors of their children within a home context. Parents' descriptions were categorized under the inappropriate behaviors theme. These behaviors included such instances as not doing the thing the child was asked to do, objection to directions from adults, disobedience, an excessive 
desire for watching television, crying after not achieving the desired thing, being overly stubborn, and resisting the completion of homework. After the interviews it was understood that parents had some basic expectations from their children, when these expectations were not met, parents regarded these behaviors as problem behaviors. To illustrate the behaviors that meet parents' expectations: children doing homework and sleeping on time, picking up toys, not eating snacks before meal times, eating his/ her meal without any help, following the directions of adults, and getting along with siblings. When these basic behaviors did not occur, parents considered this a problem. Based on this information, behaviors that did not meet the expectations of the parents or behaviors that were accepted as inappropriate by the parents were regarded as problem behaviors. Ünal (2006) stated that families considered the behaviors problematic if these did not agree with their expectations, supporting the findings of this study regarding what is considered a problem or antisocial behavior by parents.

As for the reasons that antisocial behaviors occur both at home and school, the majority of teachers and parents stated that this was caused by some family-related issue(s), such as bad attitudes, parent conflicts, young/inexperienced parents, and lack of interest. Similarly, in a study by Sadık (2002), it was noted that most of the preschool teachers, who encountered antisocial behaviors in their classes, emphasized the important role that family-life experiences have in relation to these behaviors. Additionally, demographic characteristics of the children and families in the study indicate varying circumstances that families live in (e.g., socioeconomic level, number of children, and situation of spouses, environment, culture, and education background). While the majority of the participants in the study were middle-class families, the study also included families from the lower socioeconomic level; children whose father was away from home, children who had incarcerated parents, children with divorced parents, and children who were living with grandparents tended to be in this group. In the scope of this study, it was observed, that families' social environments and economic statuses also seemed to have an effect on antisocial behaviors in children. In fact, family-related reasons for the source of antisocial behaviors included such descriptions of family factors that can be experienced under socially and economically harsh conditions; for instance, a child watching his father burn down their home while the father is inside the home. Various studies conducted on the reasons of antisocial behaviors referred to social and economic status as factors that have a formative effect on child behaviors (DeaterDeckard \& Dodge, 1997; Fraser, 1996; Gilliom \& Shaw, 2004; Şehirli, 2007). Hence, any study that aims to find out the reasons of antisocial behaviors of children in advance is suggested to consider the child with the family and environment s/he lives in, and to evaluate him or her with a holistic approach taking into account these factors.

Bronfenbrenner (1979), in his ecological theory, claims that human societies that communicate with each other and influence each other cannot be thought independent from each other. Ecological theory regards the society in the framework of systems and claims that each component in these systems (family, environment, relatives, school, friends, laws, culture, and so on) has a direct or indirect impact on development and behaviors of children. Likewise, Hill (2002) points out that the social and economic characteristics of a family, as well as the relationships within a family, have a great role in the development of antisocial behaviors. Studies on antisocial behaviors not only emphasize taking these factors into account when assessing the situation, but also note various other factors such as poverty, negative parent attitudes, education background of parents, if one of the parent's have committed a proven crime, whether mother is working or not, family structure, unsteady family life, not developing a healthy communication style with child, insufficient or strict rules, severe punishment, not or inadequately awarding proper behaviors, substance use, improper school environment and academic failure, and peer rejection (Aydoğmuş, 2010; Bullis et al., 2001; Deater-Deckard \& Dodge, 1997; Fraser, 1996; Stadelmann, Perren, Wyl, \& Klitzing, 2007; Şehirli, 2007; Yörükoğlu, 2011).

Regarding the techniques utilized by teachers and parents to cope with antisocial behaviors, teachers most frequently mentioned talking to the child about the behavior and using the in-class and out-of class break technique. Martin et al. (1999) grouped the strategies the teachers used to manage undesired behaviors under four categories: positive strategies (talking about the situation in detail with the child, supporting him by praising more positive behaviors); nonphysical punishment (verbal reprimand, exclusion); sending child to another personnel (headmaster, expert, consultant or teacher of another class) at school; and receiving help from an outsider professional. And in the 
study, they found that the teachers had a tendency to prefer nonphysical punishments and would send students to another class rather than asking for help from experts or applying the positive strategies when they faced undesired behaviors. In another study with teachers about managing antisocial behaviors, Sadik (2004) found that verbal warnings were used frequently, but those verbal warnings were not effective enough because the children were observed to demonstrate the same behavior after a while. Tulley and Chiu (1995) pointed out that the most frequent methods teachers used to cope with antisocial behaviors were to isolate the child from peers and to explain the behavior to the child. The findings from all of these studies are parallel with the findings of the present study.

Similarly, parents also frequently used the technique of talking to the children about the behavior, but the second most employed method among parents was punishment. Most of the parents stated that the methods they used to overcome antisocial behaviors were partially effective. In comparison with this finding, Bailey (2006), claimed that families had a tendency to solve the antisocial behaviors they observed in their child by having the child sit on the guilty-chair and trying to discover the course of events like a detective, then they would punish the child in an appropriate manner; however, he noted that this method was not an effective way of overcoming antisocial behaviors.

Findings of the present study revealed that to cope with antisocial behaviors, teachers needed professional support and effective programs for preventing antisocial behaviors. Webster-Stratton and Reid (2004) suggested teachers be trained in classroom management by authorized experts in the prevention of social, emotional, and behavioral problems of young children. Regarding parents' views on the issue, most of them stated that they did not take any support, but the teacher's support, from any institution or foundation related to the antisocial behaviors they observed in their children. In addition, most of the parents stated that they needed family education that would help them on how to raise a child and cope with antisocial behaviors. Özbey (2010) points out that some of the antisocial behaviors imply messages about wrong attitudes and behaviors from the parents. Parents were suggested to perceive these messages correctly and review their parental skills, and if needed they were strongly recommended to refer to seminars, books, and similar support materials and resources to improve their knowledge, particularly on child development and education. In this respect, it would be essentially important for schools to organize conferences, seminars, and related workshops on related issues.

Most of the teachers stated that the program had positive contributions in decreasing aggressive behaviors and increasing the development of social skills after the completion of the program. However, there were also teachers who thought that the program had short-term effects on students in relation to behavioral changes. Teachers' lack of cooperation with families, overcrowded classes, and lack of co-teacher support might explain this view. Similar to most of the teachers' positive feedback on the program effects, parents also stated that undesired behaviors in their children decreased after the program. As for the views of the FSS-PSV counselors, a high majority of them agreed that the program changed the behaviors of the students in a positive way. Diken and Rutherford (2005) also indicated that teachers and parents had positive feedback about the effects of the program on children, noting positive changes in terms of undesired behaviors and high satisfaction with the program among teachers. In another study, Overton et al. (2002) similarly observed positive behavior changes in the target children such as controlling behaviors, calmness, and being patient, getting on well with peers after the program, and that they were happy with the program.

In this study, FSS-PSV had positive contributions for teachers in terms of gaining skills such as time management, and being systematic and programmed. Similarly, parents and FSS-PSV counselors stated that the program had contributions to the professional development of teachers in a positive way. Apart from this, some teachers stated that they gained new insights through the program such as focusing on positive behaviors more, using verbal reinforcement, and being consistent and determined against the antisocial behaviors. They also stated that they gained new perspectives and learned a new method. In a study conducted by Diken, Bozkurt et al. (2011), teachers indicated that they had observed positive changes both in their own behaviors and in the behaviors of other students after the implementation of the program. The interviews conducted by Overton et al. (2002) with the teachers after the implementation of the intervention program revealed that the teachers learned positive teaching strategies thanks to the program; they became more patient toward children, limited children less, reinforced positive 
behaviors, and developed good communication skills with children. In other studies about the program it was found that it had promoted a positive change in teachers' own behaviors, and through this, the interaction(s) between the teacher, the target student, and other students developed in a positive way, and the teacher applied positive teaching approaches more frequently (Diken \& Rutherford, 2005; Diken, Bozkurt, et al., 2011; Golly et al., 2000; Overton et al., 2002; Özdemir, 2011; Walker, Kavanagh, et al., 1998).

A majority of the teachers and counselors noted positive contributions from the program to families as they observed positive changes in the children and the families, and the families felt happy with the implementation of the program. A majority of the parents also stated that the program helped them spend quality time with their children, and thus was beneficial for them and their children. Diken and Rutherford (2005) pointed out that families were extremely happy with the program and the outcomes they received after the application. Similarly, in the present study, families liked the program; thought that the program provided significant changes in the behaviors of their children; expressed that the program helped them spend more time with their children as the program showed them what they could do together with their children. Ünüvar's (2010) emphasized the importance of family participation in preschool education. If families and preschool education institutions act independent from each other, the desired success cannot be fulfilled; therefore, family involvement both in the home and school contexts is emphasized. For this reason, children who are educated at preschools where family participation is fostered acquire more positive behaviors and demonstrate better improvement both in academic and developmental areas (Ünüvar, 2010).
To summarize these findings, both teachers and parents are faced with antisocial behaviors, either in the school or home context. Teachers and parents in this study assumed that most factors causing antisocial behaviors originated from family. Teachers and parents would often apply some behavior management techniques to deal with antisocial behaviors; these might be effective to some extent, but there is still a need for scientifically proven valid programs that are based on school and family collaboration to guide teachers and families in solving problems. For most of the teachers who participated in the FSS-PSV program, positive changes that the program brought about among the teachers, parents, and students are evident. FSS-PSV counselors' statements also support this outcome and note the positive effects and contributions of the program for students, teachers, and parents.

The findings of the study indicate that teachers and families need extensive support in overcoming antisocial behaviors. Therefore, it is suggested that supporting school-teacher-family collaboration and organizing seminars, conferences, parental education, and in-service trainings for teachers and parents to cope with antisocial behaviors and to understand child development are very important. In addition, having psychological counseling services and guidance at preschool education institutions for families are also important. Moreover, organizing informative meetings with parents to facilitate positive and quality interactions with their children, and developing home-oriented programs for the prevention and management of antisocial behaviors are considered to be effective practices. In this respect, it is suggested that related institutions and foundations should provide support for both teachers and families in these areas. 


\section{References}

Anderson, E. M. (2007). Managing challenging behaviors in early childhood: Effect of theoretical orientation on strategy recommendation (Doctoral dissertation). University of Florida, USA. Retrieved from http://etd.fcla.edu/UF/ UFE0021571/anderson_e.pdf

Aydoğmuş, K. (2010). Ana-baba okulu (14th ed.). İstanbul: Remzi Kitapevi.

Bailey, C. M. (2006). Dealing with problem behavior. Retrieved from http://ir.library.oregonstate.edu/xmlui/bitstream/handle/1957/18923/EC\%201296-E.pdf?sequence=4

Beard, K. Y., \& Sugai, G. (2004). First step to success: An early intervention for elementary children at risk for antisocial behavior. Behavioral Disorders, 29(4), 396-409.

Blalock, E. (2008). First step to success benefits for teachers: Treatment fidelity and teachers' beliefs and behaviors about encouragement and discouragement (Doctoral dissertation). University of New Mexico, Albuquerque, USA. Retrieved from http://search.proquest.com/docview/304525959

Bronfenbrenner, U. (1979). The ecology of human development: Experiments by nature and design. Cambridge: Harvard University Press.

Brown, J. (2007). Time, space and gender: Understanding problem behavior in young children. Children \& Society, $21,98-110$

Bullis, M., Walker, H. M., \& Sprague, J. R. (2001). A promise unfulfilled: Social skills training with at-risk and antisocial children and youth. Exceptionality: A Special Education Journal, 9(1-2), 67-90.

Cameron, R. J. (1998). School discipline in the United Kingdom: Promoting classroom behavior which encourages effective teaching and learning. School Psychology, 27(1), 33-44.

Çelik, S. (2012). Problem davranıșları önlemeye yönelik başarıya ilk adım erken eğitim programı anaokulu versiyonunun etkililiği (Master's thesis, Anadolu University, Eskişehir, Turkey). Retrieved from http://tez2.yok.gov.tr

Çiftci, İ., \& Sucuoğlu, B. (2010). Bilişsel süreç yaklaşımıyla sosyal beceri öğretimi. Ankara: Kök Yayıncılık.

Davenport, B. R., Hegland, S., \& Melby, J. N. (2008). Parent behaviors in free-play and problem-solving interactions in relation to problem behaviors in preschool boys. Early Child Development and Care, 178(6), 589-607.

Deater-Deckard, K., \& Dodge, K. A. (1997). Externalizing behavior problems and discipline revisited: nonlinear effects and variation by culture, context, and gender. Journal for the Advancement of Psychological Theory, 8(3), 161-175.

Diken, İ. H., Bozkurt, F. Arıkan, A., Çolak, A., Çelik, S., Cavkaytar, E., \& Şenbalkan Tomris, G. (2011, October). Proje BİA-AV: Okulöncesi dönemde antisosyal davranışları erken önlemeye yönelik Bașarıya İlk Adım Erken Eğitim Programı anaokulu versiyonunun uyarlanması ve etkililiği: Pilot çalışma bulguları. Paper presented at the Twent Oneth National Conference on Special Educaiton, Yakın Doğu Üniversitesi, Cyprus/Kıbrıs.

Diken, İ. H., Cavkaytar, A., Batu, S., Bozkurt F., \& Kurtylmaz, Y. (2008, November). The effectiveness of the First Step to Success Early Intervention program in Turkey: Results of the pilot study. Paper presented at the meeting of the 32nd Teacher Educators for Children with Behavioral Disorders (TECBD), Tempe, Arizona, USA.
Diken, İ. H., Cavkaytar, A., Batu, S., Bozkurt F., \& Kurtyılmaz, Y. (2010). First Step to Success - a school/ home intervention program for preventing problem behaviors in young children: Examining the effectiveness and social validity in Turkey. Emotional and Behavioral Difficulties, 15(3), 207-221.

Diken, İ. H., Cavkaytar, A., Batu, S., Bozkurt F., \& Kurtyılmaz, Y. (2011). Effectiveness of the Turkish version of First Step to Success Program in preventing antisocial behaviors. Education and Science, 36(161), 145-158.

Diken, İ. H., \& Rutherford, R. B. (2005). First Step to Success Early Intervention Program: A study of effectiveness with Native-American children. Education and Treatment of Children, 28(4), 444-465.

Domenech-Llaberia, E., Claustre-Jane, M., Corbella, T., Ballespi, S., Mitjavila, M., \& Canals, J. (2008). Teacher reports of peer aggression in preschool: Its relationship to DSM-IV externalizing symptoms. The Spanish Journal of Psychology, 11(2), 433-442.

Elliot, J., Prior, M., Merrigan, C., \& Ballinger, C. (2002). Evaluation of a community intervention programme for preschool behaviour problems. Journal of Pediatrics Child Health, 38, 41-50.

Ergenekon, Y. (2012). Sosyal yeterlilikle ilişkili kavramlar ve sosyal yeterliliğin bileşenleri. In S. Vuran (Ed.), Sosyal yeterliliklerin geliştirilmesi: Sosyal beceri yetersizliği gösteren çocuklar için (pp. 17-37). Ankara: Eğiten Kitap.

Fraser, M. W. (1996). Aggressive behavior in childhood and early adolescence: An ecological-developmental perspective on youth violence. Social work, 41(4), 347-361.

Gersten, R., Baker, S., \& Lloyd, J. W. (2000). Designing highquality research in special education: Group experimental design. The Journal of Special Education, 34(1), 2-18.

Gilliom, M., \& Shaw, D. S. (2004). Co-development of externalizing and internalizing problems in early childhood. Development and Psychopathology, 16, 313-333.

Golly, A., Sprague, J., Walker, H. M., Beard, K., \& Gorham, G. (2000). The first step to success program: An analysis of outcomes with identical twins across multiple baselines. Behavioral Disorders, 25(3), 170-195.

Grossman, D. C., Neckerman, H. J., Koepsell, T. D., Liu, P. I., Asher, K. N., \& Beland, K. (1997). Effectiveness of a violence prevention curriculum among children in elementary school: A randomized controlled trial. Journal of the American Medical Association, 277(20), 1605-1611.

Hamlett, T. A. (2007). Constant analysis of aggression in television programs for preschoolers (Doctoral dissertation). University of Texas Woman's University, Child Development, Texas, USA. Retrieved from https://books. google.com.tr

Hammarberg, A., \& Hagekull, B. (2002). The relation between pre-school teachers' classroom experiences and their perceived control over child behavior. Early Child Development and Care, 172, 625-634.

Hill, J. (2002). Biological, psychological, and social processes in the conduct disorders. Journal of Child and Adolescent Psychology and Psychiatry, 43, 133-164.

Keenan, K., \& Wakschlag, L. S. (2002). Can a valid diagnosis of disruptive behavior disorder be made in preschool children? Journal of Psychiatry, 159, 351-358.

Lien-Thorne, S., \& Kamps, D. (2005). Replication study of the first step to success early intervention program. Behavioral Disorders, 31(1), 18-32. 
Martin, A., Linfoot, K., \& Stephenson J. (1999). How teachers respond to concerns about misbehavior in their classroom. Psychology in the Schools, 36(4), 347-358.

Odom, S. L., Brantlinger, E., Gersten, R., Horner, R. H., Thompson, B., \& Harris, K. R. (2005). Research in special education: Scientific methods and evidence-based practice. Council for Exceptional Children, 71(2), 137-148.

Overton, S., McKenzie, L., King, K., \& Osborne, J. (2002). Replication of the first step to success model: A multiple-case study of implementation effectiveness. Behavioral Disorders, 28(1), 40-56.

Özbey, S. (2010). Okul öncesi çocuklarda uyum ve davranıș problemleriyle başa ç kmada ailenin rolü. Aile ve Toplum Dergisi, Nisan-Mayts, 9-18.

Özbey, S., \& Alisinanoğlu, F. (2009). Okul öncesi eğitim kurumuna devam eden 60-72 aylık çocukların problem davranışlarının bazı değişkenlere göre incelenmesi. Uluslararası Sosyal Araştırmalar Dergisi, 2(6), 493-517.

Özdemir, S. (2011). The effects of the first step to success program on academic engagement behaviors of Turkish students with attention-deficit/hyperactivity disorder. Journal of Positive Behavior Interventions, 13(3), 168-177.

Rodriguez, B. J., Sheldon, M. S., Loman, L., \& Horner, R. H. (2009). A preliminary analysis of the effects of coaching feedback on teacher implementation fidelity of first step to success. Behavioral Analysis Practices, 2(2), 11-21.

Russell-Carter, D., \& Horner, R. H. (2007). Adding functional behavioral assessment to first step to success: A case study. Journal of Positive Behavior Interventions, 9(4), 229-238.

Russell-Carter, D., \& Horner, R. H. (2009). Adding function-based behavioral support to first step to success: Integrating individualized and manualized practices. Journal of Positive Behavior Interventions, 11(1), 1-11.

Sadık, F. (2002). Okul öncesi öğretmenlerin sınıf içinde karşılaştıkları problem davranışlar. Öğretmen Dünyası Dergisi, 272(23), 31-34.

Sadık, F. (2004). Okul öncesi sinıflarda gözlenen problem davranışlar ve bu davranışlarla baş etmede öğretmenlerin kullandıkları yöntemler. Eğitim Araştırmaları Dergisi, 13, 88-97.

Seeley, R. J., Small, J. W., Walker, H. M., Feil, E. G., Severson, H. H., Golly, A., \& Forness, S. R. (2009). Efficacy of the first step to success intervention for students with attention-deficit/hyperactivity disorder. School Mental Health, 1, 37-48.

Şehirli, N. (2007). Çocuk Davranışlarını Değerlendirme Ölçeği nin geliştirilmesi ve bazı değişkenlere göre incelenmesi (Master's thesis, Gazi University, Ankara, Turkey). Retrieved from http://tez2.yok.gov.tr

Singer, G. H. S., \& Wang, M. (2009). The intellectual roots of positive behavior support and their implications for its development. In W. Sailor, G. Dunlap, G. Sugai, \& R. Horner (Eds.), Handbook of positive behavior support (pp. 17-49). New York, NY: Springer Science + Business Media.

Sprague, J., \& Perkins, K. (2009). Direct and collateral effects of the first step to success program. Journal of Positive Behavior Interventions, 11(4), 208-221.

Stadelmann, S., Perren, S., Wyl, A. W., \& Klitzing, K. W. (2007). Associations between family relationships and symptoms/strengths at kindergarten age: What is the role of children's parental representations? Journal of Child Psychology and Psychiatry, 4(10), 996-1004.
Sugai, G., \& Horner, R. R. (2006). A promising approach for expanding and sustaining school-wide positive behavior support. School Psychology Review, 35(2), 245-259.

Sumi, W. C., Woodbridge, M. W., Javitz, H. S., Thornton, S. P., Wagner, M., Rouspil, K. ... Severson, H. H. (2012). Assessing the effectiveness of first step to success: Are short-term results the first step to long-term behavioral improvements? Journal of Emotional and Behavioral Disorders, 20(10), 1-14.

Tremblay, R. E. (2012). The development of physical aggression. In Encyclopedia on Early Childhood Development. Retrieved from http://www.child-encyclopedia.com/ENCA/ child-aggression/perspectives.html/

Tulley, M., \& Chiu, L. H. (1995). Students, teachers and classroom discipline. The Journal of Educational Reseach, 88(3), 164-171

Ünal, N. (2006). Okulöncesi eğitim kurumlarında görev yapan öğretmenlerin karşılaştıkları sorunlar ve çözüm önerileri (Master's thesis, Gazi University, Ankara, Turkey). Retrieved from http://tez2.yok.gov.tr

Ünüvar, P. (2010). Aile katılımı çalışmalarına yönelik ebeveyn ve öğretmen görüşlerinin karşılaştırılması. Kastamonu Eğitim Dergisi, 18(3), 719-730.

Wakschlag, L. S., Briggs-Gowan, M. J., Carter, A. S., Hill, C., Danis, B., Keenan, K. ... Leventha, B. L. (2007). A developmental framework for distinguishing disruptive behavior from normative misbehavior in preschool children. Journal of Child Psychology and Psychiatry, 48(10), 976-987.

Walker, H. M., Colvin, G., \& Ramsey, E. (1995). Antisocial behavior in schools: Strategies and best practices. Pacific Grove, CA: Brooks/Cole.

Walker, H. M., Kavanagh, K., Stiller, B., Golly, A., Severson, H. H., \& Feil, E. G. (1998). First Step to Success: An early intervention approach for preventing school antisocial behavior. Journal of Emotional and Behavioral Disorders, 6(2), 66-80.

Walker, H. M., Ramsey, E., \& Gresham, F. M. (2005). Antisocial behavior in school: Evidence-based practices (2nd ed.). Belmont, CA: Wadsworth Thomson Learning.

Walker, H. M., Seeley, J. R., Small, J., Severson, H. H., Graham, B. A., Feil, E. G. ... Forness, S. R. (2009). A randomized controlled trial of the first step to success early intervention: Demonstration of program efficacy outcomes in a diverse, urban school district. Journal of Emotional and Behavioral Disorders, 20(10), 1-16.

Walker, H. M., Severson, H. H., Feil, E. G., Stiller, B., \& Golly, A. (1998). First step to success: Intervening at the point of school entry to prevent antisocial behavior patterns. Psychology in the Schools, 35(3), 259-269.

Walker, H. M., Stiller, B., Golly, A., Kavanagh, K., Severson, H., \& Feil, E. (1997). First Step to Success: Helping young children overcome antisocial behavior. Longmont, CO: Sopris West.

Webster-Stratton, C. (2000). The incredible years training series. Retrieved from http://www.fnc.org.ar/pdfs/Basics $\% 20$ Padres.pdf

Webster-Stratton, C., \& Reid, M. J. (2004). Strengthening social and emotional competence in young children the foundation for early school readiness and success incredible years classroom social skills and problem-solving curriculum. Infants and Young Children, 17(2), 96-113. 
Webster-Stratton, C., Reid, J., \& Hammond, M. (2001) Social skills and problem solving training for children with early-onset conduct problems: Who benefits? Journal of Child Psychology and Psychiatry, 42(7), 943-952.

Webster-Stratton, C., Reid, M. J., \& Stoolmiller, M. (2008). Preventing conduct problems and improving school readiness: evaluation of the Incredible Years Teacher and Child Training Programs in high-risk schools. Journal of Child Psychology and Psychiatry, 49(5), 471-488.
Yavuzer, H. (2011). Ana-baba ve çocuk (21st ed.). İstanbul: Remzi Kitabevi.

Yavuzer, H. (2012). Doğum öncesinden ergenlik sonuna: Çocuk psikolojisi (34th ed.). İstanbul: Remzi Kitapevi.

Yörükoğlu, A. (2011). Çocuk ruh sağlı̆̆ı: Çocuğun kişilik gelişimi, eğitimi ve ruhsal sorunları (31st ed.). İstanbul: Özgür Yayınları. 